\title{
PENGGUNAAN MEDIA AUDIO VISUAL DALAM MENINGKATKAN HISTORICAL THINKING MELALUI MODEL KONTEKSTUAL
}

\author{
Rosalina \\ Program Studi Pendidikan Sejarah FKIP Universitas Lambung Mangkurat \\ Banjarmasin \\ Email : 1710111120017@ulm.ac.id
}

\begin{abstract}
Abstrak : Pembelajaran sejarah yang dirancang oleh guru harus dapat memfasilitasi peserta didik dalam mengambil makna dari peristiwa sejarah. Guru harus mendesain pembelajaran yang inovatif melalui penggunaan media berupa film dengan perpaduan model pembelajaran kontekstual sehingga dapat mengoptimalkan kemampuan peserta didik agar lebih kompeten dan juga dapat meningkatkan keterampilan berpikir historis.
\end{abstract}

Penggunaan media film ini dapat menarik perhatian peserta didik sehingga dapat mengembangkan pikiran dan pendapat serta daya fantasi peserta didik untuk meningkatkan keterampilan bepikir historis dengan model pembelajaran kontekstual yang konsep belajarnya mengaitkan antara materi yang diajarkan oleh guru dengan hubungan antara pengetahuan yang dimilikinya dengan sekitar atau situasi kehidupan nyata sehingga mendorong peserta didik untuk dapat menerapkannya dalam kehidupan mereka.

Kata kunci : Media film, historical thinking dan kontekstual

\section{PENDAHULUAN}

Perkembangan ilmu pengetahuan dan teknologi semakin mendorong upaya-upaya pembaharuan dalam pemanfaatan hasil teknologi dalam proses belajar (Cecep K, 2016:6). Sehingga menuntut para guru untuk lebih inovatif dan kreatif dalam mengajar sesuai dengan perkembangan dan tuntuan zaman. Termasuk salah satunya penggunaan media dalam pembelajaran yang diharapkan dapat meningkatkan kualitas proses belajar mengajar yang pada akhirnya akan mempengerahi kualitas hasil belajar peserta didik dan mampu meningkatkan berpikir hisoris melalu model pembelajaran yang kontekstual.

Menurut Daryanto (2010:6), Media Pembelajaran adalah segala sesuatu yang dapat digunakan untuk menyampaikan pesan, sehingga dapat menarik perhatian, minat, pikiran, perasaan peserta didik dalam kegiatan belajar untuk mencapai tujuan belajar. Media pembelajaran sejarah sendiri memiliki manfaat sebagai alat bantu untuk mengajar, terutama untuk memvisualisasikan peristiwa sejarah sedemikian rupa sehingga lebih memudahkan peserta didik untuk 
menangkap serta menghayati gambaran peristiwa sejarah. Oleh karena itulah media pembelajaran mutlak diperlukan dalam pembelajaran sejarah (Widja, 1989:60).

Mengingat pentingnya proses pembelajaran sejarah tersebut maka selayaknya pembelajaran sejarah untuk melatih kemampuan berpikir historis dengan penggunaan media audio visual dan didukung oleh model pembelajaran yang sesuai. Model pembelajaran ini akan dapat menentukan keberhasilan tujuan pembelajaran yang ingin dicapai karena melalui model pembelajaran ini guru mampu merancang aktivitas peserta didik yang terencana dengan baik dalam proses pembelajaran (Heri Susanto,2015: 28).

\section{PENGGUNAAN MEDIA AUDIO VISUAL DALAM PEMBELAJARAN SEJARAH}

Media berasal dari kata dalam bahasa Latin "medius" yang dalam bentuk jamaknya "medium", diartikan secara harfiah sebagai perantara. Karena itu, dapat dikatakan bahwa segala sesuatu yang dapat menjadi perantara disebut sebagai media (Heri Susanto\&Helmi Akmal,2019:14). Dalam kamus besar Bahasa Indonesia (1999) media merupakan alat (sarana) komunikasi seperti koran, majalah, radio, televisi, film, poster dan spanduk.

Berbagai ragam dan bentuk dari media pembelajaran, klasifikasi atas media dan sumber belajar menurut Rusman (2011: 62) yang dikutip dalam (Heri Susanto\&Helmi Akmal 2019:39) dapat juga ditinjau dari jenisnya, yaitu media audio, media visual, media audiovisual, dan media serba neka. Ada lima jenis media yang dapat digunakan dalam pembelajaran yaitu:

a. Media visual, yaitu media yang ditunjukan untuk indra penglihatan yang terdiri atas media yang dapat diproyeksikan dan media yang tidak dapat diproyeksikan yang biasanya berupa gambar diam atau gambar bergerak.

b. Media audio, yaitu media yang mengandung pesan dalam bentuk audiotif yang dapat merangsang pikiran, perasaan, perhatian, dan kemauan para peserta didik untuk mempelajari bahan ajar. Contoh dari media audio ini adalah program kaset suara dan radio.

c. Media audio-visual, yaitu media kombinasi antara audio dan visual atau biasa disebut media pandang-dengar. Contohnya adalah program video atau televisi pendidikan, video atau televisi instruksional, dan program slide suara.

d. Kelompok media penyaji. Media kelompok penyaji ini sebagaimana ungkapan Donald T. Tosti dan John R. Ball dikelompokan ke dalam tujuh jenis, yaitu: (a) kelompok kesatu; grafis, bahan cetak, dan gambar diam, (b) kelompok kedua; media proyeksi diam, (c) kelompok ketiga; media audio, (d) 
kelompok keempat; media visual, (e) kelompok kelima; media gambar hidup/film, (f) kelompok keenam; media televisi, dan (g) kelompok ketujuh; multimedia.

e. Media objek dan media interaktif berbasis komputer, merupakan media tiga dimensi yang menyampaikan informasi tidak dalambentuk penyajian, melainkan melalui ciri fisiknya sendiri, seperti ukurannya, bentuknya, beratnya dan susunannya, warnanya, fungsinya, dan lain sebagainya. Media ini dibagi ke dalam dua kelompok, yaitu media objek sebenarnya dan media objek pengganti. Sedang media interaktif berbasis komputer adalah media yang menuntut peserta didik untuk berinteraksi selain melihat maupun mendengarkan.

Media audiovisual adalah media yang mampu merangsang indra penglihatan dan indra pendengaran secara bersama-sama, karena media ini mempunyai unsur suara dan unsur gambar (Djamarah, 2006: 124). Media audiovisual adalah media yang bersifat dapat didengar dan dilihat (Soendojo Dirdjosoemarto,2000: 19).

Media Pembelajaran Audiovisual adalah satu unit media pembelajaran elektronik yang secara bersama-sama menampilkan auditif (pendengaran) dan visual (penglihatan) sebagai sumber belajar dan sebagai penyalur informasi dari bahan-bahan pelajaran yang disampaikan guru kepada peserta didik dalam proses belajar mengajar. Menurut Nasution (1999), menggunakan film dalam pendidikan dan pengajaran di kelas sangat berguna atau bermanfaat terutama untuk Mengembangkan pikiran dan pendapat para peserta didik, Menambah daya ingat pada pelajaran, Mengembangkan daya fantasi peserta didik, Menumbuhkan minat dan motivasi belajar.

Pembelajaran merupakan proses yang sangat membutuhkan banyak sumber untuk menunjang proses pembelajaran. Semakin banyak sumber yang diperoleh maka akan mempermudah proses pembelajaran dan mampu mencapai tujuan dari proses pembelajaran yang diinginkan secara optimal.

Pada konteks pembelajaran sejarah, desain pembelajaran sejarah yang dirancang guru harus dapat memfasilitasi peserta didik dalam mengambil makna dari peristiwa sejarah. Penting mengambil makna, karena pembelajaran sejarah dapat mengembangkan berbagai potensi dasar peserta didik seperti nilai-nilai kearifan, watak dan kepribadian. Pembelajaran sejarah yang ideal yakni yang mampu memfasilitasi peserta didik untuk dapat mencapai tujuan pembelajaran secara optimal. guru harus mendesain pembelajaran yang inovatif, sehingga dapat mengoptimalkan kemampuan peserta didik agar lebih kompeten. Pembelajaran sejarah yang inovatif dan kreatif, selain dapat meningkatkan profesionalisme 
pendidik juga dapat mengembangkan kompetensi peserta didik terkait dengan materi sejarah (Shintya E, Nurul U, Sumardi, 2019:2).

Pembelajaran sejarah yang baik akan membentuk pemahaman sejarah. Pemahaman sejarah merupakan kecenderungan berfikir yang merefleksikan nilainilai positif dari peristiwa sejarah dalam kehidupan sehari-hari, sehingga kita menjadi lebih bijak dalam melihat dan memberikan respon terhadap berbagai masalah kehidupan. Pemahaman sejarah memberi petunjuk kepada kita untuk melihat serangkaian peristiwa masa lalu sebagai sistem tindakan masa lalu sesuai dengan jiwa jamannya, akan tetapi memiliki sekumpulan nilai edukatif terhadap kehidupan sekarang dan akan datang (Heri Susanto, 2014:36)

Apabila pembelajaran sejarah telah dipahami dengan baik dalam upaya menanamkan nilai-nilai kehidupan, maka hasil belajar yang diharapkan adalah peserta didik mampu menanamkan nilai-nilai tersebut dalam kehidupan seharihari, seperti yang sering dikemukakan nilai tersebut antara lain; kesadaran waktu, menghargai waktu, sikap kritis, menghargai peninggalan sejarah dan memiliki sikap nasionalisme (Heri Susanto, 2015:30)

\section{HISTORICAL THINKING DAN PENGGUNAAN MEDIA AUDIO VISUAL}

Keterampilan berpikir kesejarahan didefinisikan sebagai seperangkat keterampilan berpikir yang menjadikan peserta didik harus belajar dari sejarah (Murni, 2006:82). Berpikir sejarah menurut Fischer yang dikutip langsung oleh Zed adalah bersifat "aduktif" yaitu mengajukan pertanyaan kritis dan memberikan jawaban dengan argumen historis atau berdasarkan bukti-bukti faktual (Zed, 1999:27).

Menurut Sjamsuddin dengan belajar sejarah seseorang memperoleh pemahaman atau apresiasi tentang orang-orang, peristiwa-peristiwa atau periodeperiode tertentu dari masa lalu yang dikaji. Bahwa peserta didik memerlukan "Knowldge and reasoning skills for effective functioning in the Age" (Pengetahuan dan keterampilan-keterampilan memberi fungsi efektif dalam perkembangan kemampuan seseorang) (Sjamsudin, 2007:201).

Berdasarkan pendapat di atas maka pembelajaran sejarah harus memberikan kesempatan kepada peserta didik untuk mengembangkan pengetahuan dan pemahamannya mengenai peristiwa sejarah dan kemampuan berpikir dalam sejarah. Bahwa berpikir terdiri dari atau proses menegakkan hubungan kausalitas, mengubah dan menetapkan keterkaitan antara apa yang sudah diketahui dengan yang belum diketahui sehingga menghasilkan makna, kemampuan mencari hubungan antara berbagai informasi sehingga dapat 
mengenal dan menemukan regularisitas, kemampaun mengklasifikasikan berdasarkan kemampaun menemukan ciri khas suatu peristiwa.

Pemahaman sejarah perlu dimilik setiap orang sejak dini agar mengetahui makna dari setiap peristiwa masa lampau sehingga dapat digunakan sebagai landasan sikap dalam menghadapi kenyataan pada masa sekarang dan juga untuk menentukan langkah terbaik di masa yang akan datang. (Heri Susanto, 2014:42)

Keterampilan berpikir kesejarahan yang sangat relevan adalah yang mengacu pada National Standard For United State History yang terdiri dari : (1) keterampilan berpikir kronologis (Cronological thinking), (2) pemahaman sejarah (Historical Comprehension), (3) analisis dan interpretasi sejarah (Historical analysis and interpretation), (4) kemampuan melakukan penelitian sejarah (Historical Research Capabilities) serta (5) analisis isu kesejarahan dan pengambilan keputusan (Historical Issues-Analysis and decision making).

Sementara itu dalam kategori Centre for Study of Historical Conciuosness meletakkan historical thinking pada pilar:

1. Membangun makna sejarah (establish historical significance)

2. Kecenderungan menggunakan sumber primer (use primary source evidence)

3. Mengidentifikasi perubahan dan keberlanjutan (identify continuity and change)

4. Menganalisis sebab dan akibat (analyze cause and consequence)

5. Menggunakan sudut pandang sejarah (take historical perspectives)

6. Memahami dimensi etis dari interpretasi sejarah (understand the ethical dimension of historical interpretations)

Keenam pilar tersebut menjadi satu kesatuan dalam cara berpikir sejarawan yang dapat diilustrasikan dalam gambar;

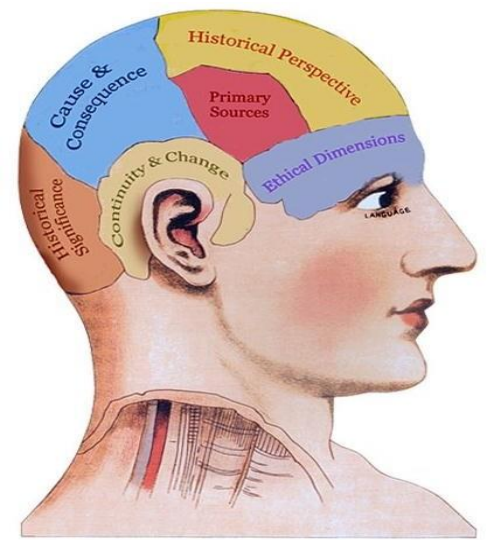

Sumber : Centre For Study of Historical Conciousness (Kanada) 
Keberhasilan proses pembelajaran bergantung kepada penggunaan sumber dan media pembelajaran yang sesuai. Jika sumber dan media dipilih dan dipersiapkan dengan tepat dan hati-hati dapat memenuhi antara lain; menimbulkan motivasi positif peserta didik, melibatkan peserta didik, mejelaskan dan menggambarkan isi subjek, dan menggambarkan kinerja individual. Melalui hal ini dapat diketahui bahwa kedudukan media dalam pembelajaran tidak dapat dianggap sepele. Perlu diperhatikan bahwa materi ajar yang berbeda memerlukan media dan sumber pembelajaran yang berbeda pula (Heri Susanto\&Helmi Akmal, 2019:30)

Multimedia pembelajaran sejarah secara sederhana dapat diartikan sebagai integrasi berbagai media (visual, audio, audio-visual) dalam sebuah media yang berfungsi untuk menyampaikan materi ajar sejarah kepada peserta didik. Multimedia adalah kombinasi dari komputer dan video (Rosch, 1996) atau multimedia secara umum merupakan kombinasi tiga elemen, yaitu suara, gambar dan teks (McCormick, 1996). Multimedia juga diartikan sebagai kombinasi dari paling sedikit dua media input atau output dari data, dapat berupa media audio (suara, musik), animasi, video, teks, grafik dan gambar (Turban dkk, 2002) atau pula merupakan alat yang dapat menciptakan presentasi yang dinamis dan interaktif yang mengkombinasikan teks, grafik, animasi, audio dan gambar video (Robin dan Linda, 2001) dalam kutipan (Heri Susanto\&Helmi Akmal, 2019:7475)

Jika diilustrasikan, multimedia dapat digambarkan sebagai berikut;

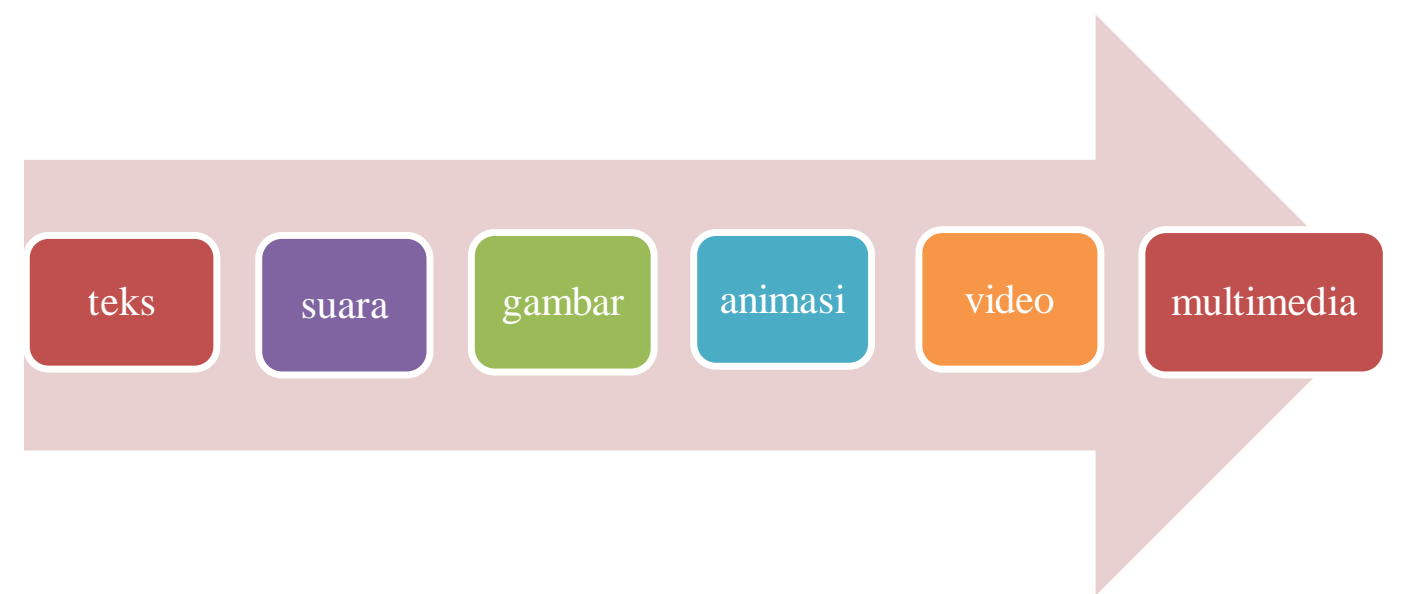

sumber: adaptasi dari Heri Susanto\&Helmi Akmal, (2019: 75)

Keterampilan berpikir kesejarahan ini tidak langsung dimiliki oleh peserta didik tetapi harus melalui proses yang sifatnya kontinuitas melalui proses pembelajaran. Pembangunan keterampilan berpikir sejarah ini hanya dapat terbangun apabila peserta didik sering diajak melakukan keterampilan berpikir 
tingkat tinggi. Salah satu cara yang paling efektif membangun keterampilan berpikir kesejarahan peserta didik dengan menerapkan metode atau model yang tepat, khususnya metode atau model yang dapat mengajak peserta didik untuk bernalar, melakukan analisis dan berpikir kritis. Sehingga jika guru hanya menerapkan metode atau model yang sederhana tujuan membangun keterampilan berpikir kesejarahan ini tidak akan terjadi. Hal ini harus dipertimbangkan oleh guru karena berdasarkan penelitian keterampilan berpikir sejarah yang tinggi berdampak pada prestasi berlajar yang tinggi pula.

\section{MODEL KONTEKSTUAL UNTUK MENINGKATKAN HISTORICAL THINKING}

Keterampilan berpikir kesejarahan didefinisikan sebagai seperangkat keterampilan berpikir yang menjadikan peserta didik harus belajar dari sejarah (Murni, 2006:82). Berpikir sejarah menurut Fischer yang dikutip langsung oleh Zed adalah bersifat "aduktif" yaitu mengajukan pertanyaan kritis dan memberikan jawaban dengan argumen historis atau berdasarkan bukti-bukti faktual (Zed, 1999:27).

Menurut Harada (2005:27), ada empat cara meningkatkan cara berpikir kesejarahan peserta didik yaitu pertama, guru harus mengajak peserta didik berpikir tentang materi aktual yang ada disekitar mereka. Kedua, guru tidak lagi terpaku pada buku teks tetapi guru harus mengarahkan dan memberikan pertanyaan-pertanyaan dari materi sejarah dengan menstimulasi peserta didik untuk berpikir dan mengajak peserta didik untuk melakukan penemuan. Ketiga, jika pembelajaran harus menggunakan buku teks maka yang dilakukan adalah mengajak peserta didik melakukan penelitian sistematis dan melakukan koreksi terhadap buku teks sehingga peserta didik terstimulasi untuk belajar. Isi buku teks digunakan untuk menemukan permasalahan dan menarik hipotesis. Keempat, kurikulum sejarah haruslah sistematis sehingga peserta didik dapat melakukan penemuan dalam proses pembelajarannya.

Model pembelajaran Contextual Teaching and Learning (CTL) atau biasa disebut kontekstual adalah suatu strategi pembelajaran yang menekankan kepada proses keterlibatan peserta didik secara penuh untuk dapat menemukan materi yang dipelajari dan menghubungkannya dengan situasi kehidupan nyata sehingga mendorong peserta didik untuk dapat menerapkannya dalam kehidupan mereka (Sanjaya, 2006: 255). 
Pembelajaran kontekstual (Contextual Teaching and Learning) adalah konsep belajar yang membantu guru mengaitkan antara materi yang diajarkannya dengan situasi dunia nyata peserta didik mendorong peserta didik membuat hubungan antara pengetahuan yang dimilikanya dengan penerapannya dalam kehidupan mereka sehari-hari, dengan melibatkan tujuh komponen utama belajar efektif yakni: kontruktivisme (Constructivism); bertanya (Questioning); menemukan (Inquiri); masyarakat belajar (Learning Community); pemodelan (Modeling); dan penilaian sebenarnya (Authentic Assessment) (Daryanto \& Rahardjo, 2012: 155).

Menurut Johnson dalam Nurhadi (2003:13), ada 8 komponen yang menjadi karakteristik dalam pembelajaran kontekstual, yaitu sebagai berikut:

1. Melakukan hubungan yang bermakna (Making Meaningfull Connection). Keterkaitan yang mengarah pada makna adalah jantung dari pembelajaran kontekstual. Ketika peserta didik dapat mengkaitkan isi dari mata pelajaran akademik tertentu dengan pengalaman mereka sendiri, mereka menemukan makna dan makna memberikan alasan untuk belajar. Mengkaitkan pembelajaran dengan kehidupan seseorang membuat proses belajar menjadi hidup dan keterkaitan inilah inti dari CTL.

2. Melakukan kegiatankegiatan yang signifikan (doing significant work). Peserta didik membuat hubungan-hubungan antar sekolah dan berbagai konteks yang ada dalam kehidupan nyata sebagai pelaku bisnis dan sebagai anggota masyarakat. Jadi, pembelajaran harus memiliki arti bagi peserta didik.

3. Belajar yang diatur sendiri (selfregulated learning). Pembelajaran yang diatur sendiri merupakan pembelajaran yang aktif, mandiri, melibatkan kegiatan yang menghubungkan masalah dengan kehidupan sehari-hari dengan cara yang berarti bagi peserta didik. Pembelajaran yang diatur peserta didik sendiri, memberi kebebasan kepada peserta didik menggunakan gaya belajarnya sendiri.

4. Bekerja sama (collaborating). Peserta didik dapat bekerja sama. Guru dan peserta didik bekerja secara efektif dalam kelompok, guru membantu peserta didik memahami bagaimana mereka saling mempengaruhi dan saling berkomunikasi.

5. Berpikir kritis dan kreatif (critical and creative thinking). Peserta didik dapat menggunakan tingkat berpikir yang lebih tinggi secara kritis dan kreatif. Berpikir kritis adalah suatu kecakapan nalar secara teratur, kecakapan sistematis dalam menilai, memecahkan masalah, menarik keputusan, memberi keyakinan, menganalisis asumsi dan pencairan ilmiah. Berpikir kreatif adalah suatu kegiatan mental untuk meningkatkan kemurnian, ketajaman pemahaman dalam mengembangkan sesuatu. 
6. Mengasuh atau memelihara pribadi peserta didik (nurturing the individual). Dalam pembelajaran kontekstual peserta didik bukan hanya mengembangkan kemampuan-kemampuan intelektual dan keterampilan, tetapi juga aspekaspek kepribadian seperti integritas pribadi, sikap, minat, tanggung jawab, disiplin, motif.

Adapun beberapa tujuan dari pembelajaran Kontekstual ini, yakni sebagai berikut :

1. Memotivasi peserta didik untuk memahami makna materi pelajaran yang dipelajarinya dengan mengkaitkan materi tersebut dengan konteks kehidupan mereka sehari-hari.

2. Agar dalam belajar peserta didik tidak hanya sekedar menghafal tetapi diperlukan juga pemahaman terhadap materi.

3. Menekankan pada pengembangan minat pengalaman peserta didik.

4. Melatih peserta didik agar dapat berpikir kritis dan terampil dalam memproses pengetahuan agar dapat menciptakan sesuatu yang bermanfaat bagi dirinya sendiri dan orang lain.

5. Pembelajaran yang dialami peserta didik lebih bermakna.

6. Mengajak peserta didik pada suatu aktivitas yang mengkaitkan materi akademik dengan konteks kehidupan seharihari (Sanjaya, 2006: 17).

Secara garis besar, langkah-langkah model pembelajaran CTL sebagai berikut: 1) Kembangkan pemikiran bahwa peserta diidk akan belajar lebih bermakna dengan cara bekerja sendiri, dan mengkontruksi sendiri pengetahuan dan keterampilan barunya; 2) Laksanakan sejauh mungkin kegiatan inquiri untuk semua topik; 3) Kembangkan sifat ingin tahu siswa dengan bertanya; 4) Ciptakan masyarakat belajar; 5) Hadirkan model sebagai contoh pembelajaran; 6) Lakukan refleksi diakhir pertemuan; 7) berbagai cara (Daryanto dan Rahardjo, 2012: 156).

Guru mengembangkan pemikiran tentang peserta didik, bahwa peserta didik akan belajar lebih baik dengan cara bekerja sendiri, mengkronstruksi sendiri pengetahuan dan keterampilan barunya dengan melaksanakan kegiatan inquiri dalam semua topik atau materi. Menciptakan masyarakat belajar dengan saling bertukar pikiran antar teman sebangku. Guru menghadirkan model pembelajaran dengan menarik peserta didik untuk dijadikan contoh dalam pembelajaran. Diakhiri pertemuan, peserta didik melakukan refleksi dan guru melakukan penilaian yang sebenarnya dengan berbagai cara. Sehingga hal ini dapat meningkatkan berpikir historis peserta didik karena aktif dalam proses pembelajaran dan didukung dengan penggunaan media audio visual yang dapat menarik perhatian dan semangat peserta didik dalam pembelajaran sejarah dan 
dipastikan penggunaan media ini dibuat dengan sekreatif dan inovatif mungkin oleh guru.

\section{PENUTUP}

Media Pembelajaran Audiovisual adalah satu unit media pembelajaran elektronik yang secara bersama-sama menampilkan auditif (pendengaran) dan visual (penglihatan) sebagai sumber belajar dan sebagai penyalur informasi dari bahan-bahan pelajaran yang disampaikan guru kepada peserta didik dalam proses belajar mengajar. Pembelajaran sejarah dapat memfasilitasi peserta didik dalam mengambil makna dari peristiwa sejarah. Penting mengambil makna, karena pembelajaran sejarah dapat mengembangkan berbagai potensi dasar peserta didik seperti nilai-nilai kearifan, watak dan kepribadian.

Untuk meningkatkan kemampuan historical thinking peserta didik maka didukung dengan model pembelajaran kontekstual / Contextual Teach and Learning dapat membantu peserta didik dalam proses pembelajaran dan dengan demikian peserta didik tidak hanya menerima informasi baku dari guru namun bisa menemukan dan mengolah pengetahuan dan informasi secara mandiri.

\section{DAFTAR PUSTAKA}

Cecep Kustandi. 2016. Media Pembelajaran. Bogor : Ghalia Indonesia

Daryanto. 2010. Media Pembelajaran. Bandung : Satu Nusa

Daryanto dan Muljo Rahardjo. 2012. Model Pembelajaran Inovatif. Yogyakarta:

Gava Media.

Depdikbud. 1999. Kamus Besar bahasa Indonesia. Jakarta: Balai Pustaka

Dirdjosoemarto, Soendojo. 2000. Media Pembelajaran. Jakarta : Depdikbud

Djamarah, Syaiful Bahri dan Aswan Zain. 2006. Strategi Belajar Mengajar. Rineka Cipta: Jakarta

Harada, Tomohito. 2005. Consistency Of History Curriculum In Primary and Secondary School. Jurnal Studi Sosial Vol 1.Yogyakarta: Hispisi.

Murni. 2006. Model Pembelajaran Holistik Dalam Pengembangan Keterampilan Berpikir Kesejarahan, Desertasi. Bandung: PPS UPI 
Nasution, S. 1999. Kurikulum dan Pengajaran. Jakarta: Bumi Aksara

Nurhadi. 2003. Pendekatan Kontekstual. Jakarta: Departemen Pendidikan Nasional.

Sanjaya, Wina. 2006. Strategi Pembelajaran. Jakarta: Kencana Prenadamedia Gruop.

Shintya E, Nurul U, Sumardi. The Effectiveness Of Prezi Media For History Learning Of The Eleventh Grade. Jurnal Historica. 2019 vol. 3

Sjamsuddin, Helius. 2007. Penulisan Buku Teks dan Sejarah Lokal dalam Buku Sejarah Lokal Penulisan dan Pembelajaran di Sekolah. Bandung : Salamian Perss.

Susanto, Heri. 2014. Seputar Pembelajaran Sejarah Isu, Gagasan, dan Strategi Pembelajaran. Yogyakarta : Asswaja Pressindo

Susanto, H. (2015). Menghadirkan Kelas Konstruktivis dalam Melatih Kemampuan Berpikir Historis Melalui Model Latihan Penelitian.

Susanto Heri \& Helmi Akmal. 2019. Media Pembelajaran Sejarah Era Teknologi Informasi. Banjarmasin : Program Studi Pendidikan Sejarah Fakultas Keguruan dan Ilmu Pendidikan Universitas Lambung Mangkurat

Widja, I Gde. 1989. dasar-dasar Pengembangan Strategi Serta Metode Pembelajaran Sejarah. Jakarta : Depdikbud

Zed, Mestika. 1999. Metodologi Sejarah. Padang : FIS UN 